\title{
URGENCY RIJALUL POSTING IN PREVENTING HOAX: QURANIC PERSPECTIVE
}

\author{
Doli Witro \\ Institut Agama Islam Negeri (IAIN) Kerinci \\ Email:doliwitro01@gmail.com
}

\begin{abstract}
$I$

ndonesian Ministry of Communication and Information stated in 2017 that it had blocked 800 thousand harmful contents, including hoax (fake news). However, Masyarakat Telematika (Mastel) Indonesia reported the results of a survey in 2019 that there were $34.60 \%$ of respondents received hoax every day. Hoaxes will have implications for harmony in society and are even very vulnerable to riots. This study uses a qualitative method with a literature review design that study the analogy between hadith and posts of Internet users that are both news or information. Hadith is information from the Prophet p.b.u.h., while posting is information that comes from Internet users. Based on this it is important to see the scholars of hadith in conveying, accepting the hadith, and including it in their respective books. To find out whether or not a hadith is correct, rawi examines sanad and matan hadith. In the hadith science, the study of the hadith discussed in the science of rijalul hadith. In rijalul, this post will be examined on how to explore the content of the Internet media. Of course, this is in accordance with the indicators (adl, dhabit, ittishal alsanad, bighayr illat, and bighayr syadz) in the science of rijalul hadith, and the perspective of Al-Quran will be examined. Rijalul Posting is divided into two; al-urwah date account (how to clarify posts by looking at the identity and account history) and al-jarh wa ta'dil content account (how to clarify posts). Indicators used: fair information, date of posting, clear source, complete, and polite language. Thus, these posts can be shared on websites or social media.
\end{abstract}

\section{Keywords: Rijalul Hadith, Posting, Hoax}




\begin{abstract}
ABSTRAK
$\mathrm{K}$ ementerian Komunikasi dan Informatika (Kemenkominfo) menyatakan pada tahun 2017 telah memblokir 800 ribu konten negatif termasuk di dalamnya yang bermuatan hoax (berita bohong). Namun demikian, Masyarakat Telematika (Mastel) Indonesia melansir hasil survei yang menyebutkan bahwa pada tahun 2019, terdapat sebanyak 34,60\% responden menerima berita hoax setiap hari. Hoax akan berdampak pada keharmonisan dalam masyarakat dan bahkan sangat rentan terhadap kerusuhan. Penelitian ini menggunakan metode kualitatif dengan desain tinjauan pustaka yang mempelajari analogi antara hadis dan tulisan pengguna Internet yang merupakan berita atau informasi. Hadits merupakan informasi dari Nabi s.a.w., sementara postingan merupakan informasi yang berasal dari pengguna internet. Berdasarkan hal ini penting kiranya melihat para muhadits (pemerhati) dalam menyampaikan, menerima hadits, dan mencantumkannya ke dalam kitab mereka masingmasing. Untuk mengetahui benar tidaknya suatu hadits, maka perlu dicermati sanad dan matan hadits. Dalam ilmu hadits kajian tentang sanad hadits dibahas dalam ilmu rijalul hadits. Berangkat dari istilah ini penulis hendak menawarkan analogi istilah rijalul posting dengan rijalul hadits. Dalam rijalul posting ini akan dikaji cara meneliti postingan-postingan yang terdapat dalam media internet. Tentu, ini tidak lepas dari indikator-indikator (adil, dhabit, sanadnya bersambung, tidak illat, dan tidak syadz) yang ada dalam ilmu rijalul hadits dan akan ditelaah menurut perspektif Al-Quran. Rijalul Posting dibagi menjadi dua; akun tarikh al-urwah (cara memperjelas posting dengan melihat identitas dan riwayat akun) dan akun konten al-jarh wa ta'dil (cara memperjelas posting). Indikator yang digunakan: informasi yang adil, tanggal posting, kejelasan sumber, lengkap , dan bahasa sopan. Dengan demikian maka postingan tersebut dapat dibagikan di situs web atau media sosial.
\end{abstract}

Kata Kunci: Rijalul Hadits, Posting, Hoax. 


\section{INTRODUCTION}

Indonesian Ministry of Communication and Information stated in 2017 that it had blocked 800 thousand harmful contents, including hoax (fake news) (Kominfo, 2019). However, Masyarakat Telematika (Mastel) Indonesia (2019) -Institutions engaged in the fields of technology, information, communication, and broadcasting reported- the results of a survey said that in 2019 , there were $34.60 \%$ of respondents received hoax every day. There are many types of hoaxes received, some of which are social politics (93.20\%), followed by Tribe, Religion, Race and Intergroup (Suku, Agama, Ras dan Antargolongan/SARA) (76.20\%), then about government $(61.70 \%)$. While the most widely used media is social media $(87.50 \%)$, followed by chat applications $(67.00 \%)$, then websites $(28.20 \%)$. The problem of spreading hoax in cyberspace seems to be a severe concern for the government with the advent of negative content scavenger machines (AIS), which are worth hundreds of billions of rupiah (Kominfo, 2019). Besides, the government also provides aduankonten.id site to clarify doubtful news.

The hoax has implications for the harmony of the community and even ranges from riots. This is evident when hoax enters the Wamena Papua community regarding racist words delivered by a teacher at school. When it was clarified that the teacher never conveyed the racist term. As a result of this hoax, dozens of residents have become victims of murder; residents; houses were burned; the people of Wamena destroyed agency offices (Detiknews, 2019). The assumption that is built from this case is that the community needs a critical ability to clarify every news/ information to check the story received to the source (first) so that it can be concluded that the story is true or not.

In the Oxford Learner's Pocket Dictionary, it is mentioned that hoax is deceived somebody with a hoax (Oxford University, 2011: 211). A hoax is a piece of news; it's just the substance or information is false or lies (Wirdiyana, 2019: 147; Sellnow, Parrish, \& Semenas, 2019: 125; Allcott and Gentzkow, 2017: 213; Rachman, 2019).

There are so many verses in the Qur'an that mention lies Q. S. 7: 20-21 about Satan deceiving the Prophet Adam a.s.; Q. S. 49: 6 orders to clarify the wicked bring the message; Q. S. 12: 8-18 and 25-29 about false news that befell the Prophet Joseph a.s. when I was a child and a teenager: Q. S. 24: 11-15 about slander that befell Aysah r.a. wife of Rasulullah p.b.u.h. who is accused of adultery.

The spread of this hoax is natural for people with low literacy levels because they do not think long about every news received, they easily repost news that they find interesting, while they do not know that what is posted is a hoax (Maulana, 2017: 210; Aziz, 2018: 130; Adli \& Sulaiman, 2018: 161-162; Balmas, 2014: 432).

Departing from the above problems, it is essential to see the hadith scholars in conveying and receiving traditions. Hadith is everything that comes from the Prophet p.b.u.h. the words, deeds and taqrir (approval) of the Prophet p.b.u.h. an event. This is where there are similarities with the posts of Internet users that are both news or information. Hadith is information from the Prophet p.b.u.h., while posting is information that comes from Internet users.

To find out whether or not a hadith is correct, rawi examine sanad and matan. 
Sanad is the people who convey the hadith that are interconnected with each other until finally to the Prophet p.b.u.h. While matan is the content or text of the hadith itself (alKhatib, 1975: 19), people who are in sanad in a hadith must be examined their identity one by one with the indicators that have been determined, for example, whether he is a person who can be trusted (tsiqah) or not, whether he has intense memorization (dhabit) or not, and not etcetera. When all indicators have been fulfilled, then the hadith that was conveyed can be accepted. But on the contrary, if the hadith that was submitted did not meet the requirements; then, the hadith was rejected (Imron, 2017: 288).

It should be the same as accepting and posting a post that comes from the Internet, both from the website and social media. An Internet user must examine the person who posted it first to the source. Likewise, with the contents of the post itself, whether it is a correct editor or not, whether it has invited to the good or not, and so forth. If the source can identify the post and the content does not lead to badness, then the post can be shared on the Internet.

Therefore, in the science of hadith, the study of hadith is discussed in the realm of rijalul hadith science. Departing from this term, the author would like to offer an analogy to the term rijalul posting. In the sphere of rijalul assignment will be examined how to examine the posts contained on the Internet. Of course, it cannot be separated from the indicators that exist in the science of rijalul hadith. When the signs are formulated, the perspective of Al-Quran will be explored. The author feels it is essential to discuss and study given the rise of hoax circulating on the Internet. This study aims to ward off hoax so that people who use the Internet can clarify every post they receive.

\section{METHODOLOGY}

This study is a qualitative study with a literature review design that describes in general terms about hoaxes and hoax clarification methods by using rijalul posting from the verses of the Al-Quran, which are juxtaposed with theoretical studies and other related research results. Material or data sources in this study were obtained from books, journals, articles, the Internet, and others related to the traditions of hadith and hoaxes. After the data is collected, it is then analyzed by the analytical method introduced by Miles and Huberman, namely data reduction, data presentation, and concluding (Miles and Huberman, 1984: 21-24).

\section{RESULTS AND DISCUSSION \\ 1. Rijalul Posting Concept}

Rijalul hadith is interpreted literally as people around the traditions (Mukhtar, 2011: 188). While according to the term rijalul hadith means the science of hadith, which studies the narrators of the traditions in their capacity as narrators of the traditions (al-Shaleh, 1998: 110). According to Hasbi ash-Shiddieqy (1991: 153), the science of rijalul hadith is a science that discusses rawi both from among the sahabat, tabi'in, and later generations who narrated a hadith. From some of these definitions, it can be understood that rijalul hadith is a discipline of tradition that discusses the narrator's personalities in terms of their ability to narrate the hadith.

In the term rijalul posting, two words need to be understood, namely rijal and posting. Rijal has the same meaning as the above definition, namely, people who are 
around something while posts are from English, post, which, if translated in Indonesian means pos. "Kamus Besar Bahasa Indonesia Dalam Jaringan (KBBI Daring, 2019) the pos means a process in which is carried out sending goods, money, and so forth". The post in Internet terms means the content uploaded or put on the Internet in the form of text, video, and photos. The process of inserting and uploading content to social media and websites is called posting (Santoso et al., 2017: 218). While the circumstances in which the content appears on the Internet both through websites and social media are viewed by Internet users, the people who see it named the content by postingly. Based on the description above, it can pull the meaning of the original posts of the people who are around the posts, those who make posts, people who receive posts, and people who will repost the content they receive on the Internet media.

Furthermore, in rijalul hadith is divided into two parts, namely the science of tarikh al-ruwah and the science of aljarh wa ta'dil. According to Muhammad Ujaj al-Khatib, the science of tarikh alruwah is the study of the narrators of traditions relating to their narration of cultures, starting from mentioning the general condition of the narrators such as the year of birth and death, the teachers, when he heard and wrote the hadith and narrate it while the science of al-jarh wa ta'dil is the study of criticism of the narrators of the traditions about the advantages and disadvantages they have.

From the two divisions of the rijalul hadith science above, the writer wants to divide the rijalul posts into two parts that cannot be separated from the rijalul hadith, namely tarikh al-ruwah account and al-jarh wa ta'dil content. Tarikh al-ruwah account is how an Internet user sees the posts of other Internet users in general. That is, he checks or goes into the account that posted a piece of content then sees the identity and history (previous posts).

While al-jarh wa ta'dil content is a way in which Internet users examine the posts of an account specifically. In al-jarh wa ta'dil content, the author takes the conditions of authentic hadith, i.e., the rawi must be fair, be dhabit (good memory), sanad of the hadith is continued, bighayr illat, and bighayr syadz (odd) (Solahudin \& Suyadi, 2009: 15). From the conditions of the authentic hadith, the author analogues into al jarh wa ta'dil content, including: 1) Internet users must be fair in loading posts that are not credited by one party or another person; 2) Internet users must be sensitive and careful about the date of a post. Because it may be that the post that was posted is already happening in the past; 3 ) every post that will be uploaded must have a bright source. That is, Internet users must include the basis on which they are posted; 4) the posts contained on the Internet must be complete and not only half of it or cut up even if the post includes something correct; 5) posts posted on the Internet must be presented neatly and must use polite language, also though they contain criticism directed at someone.

\section{Contextualization of Rijalul Posting in Prevent Hoax: Quranic Perspective}

It fits for Muslims to be proud because they know receiving information. If seen from the development of technology and data in processing any information from recording devices (cameras, computers) delivered by a character or resource person in an event on television. Technology can only display the knowledge delivered but has not been able to display morals. The validity of education delivered by an actor 
on television is measured by the intellectual level he has. But unlike the case in the science of rijalul hadith, besides a rawi measured by the intellectual he has and the rawi morals must also be known (Sohari, 1997: 25). Because if not, the narrator might be the news anchor hoax for personal, political, and ideological interests (Khotimah, 2019: 135; Witro, 2019: 16).

For example, as a false hadith conveyed by Abdullah bin Saba': "Every prophet has a will, and the recipient of my will is Ali". This fake hadith was intended to overthrow Uthman bin Affan during his reign then lift Ali into the caliph. But his efforts failed because many senior friends were still alive at the time who knew that the hadith was never delivered by the Prophet p.b.u.h. (Solahudin \& Suyadi, 2009: 173). Hoaks related to religious issues not only occur in the past, but now also many similar things occur, especially in Indonesia (Alimi, 2019: 125), for example, the hoax to bring someone down has been carried out by a person who accuses Ustadz Abdul Somad of having an affair with a woman using Said Didu Twitter account. This is intended to bring down the pride of Ustadz Abdul Somad in public. However, when confirmed and clarified, Said Didu admitted that certain elements hacked his Twitter account (Stophoax.id, 2019). Seeing events like this is essential to the public to know the substance of information before justifying someone with a bad. This is where the role of posting is as a skill (ability) to find out the content of information received from the Internet as it is known that the posts are divided into two parts, namely tarikh alruwah account and al-jarh wa ta'dil content.

\section{a. Tarikh al-Ruwah Account}

Tarikh al-ruwah account is the first thing to do when receiving or viewing posts on the internet both through websites and social media. Tarikh al-ruwah account is done by looking at the identity of the internet user account and also the previous posting of the account. Similar to someone who will learn, so he finds out who the teacher (find out identity). Because teachers have good morality, the knowledge they convey is real knowledge. This is implied in the word of Allah in surah az-Zumar verse 9:

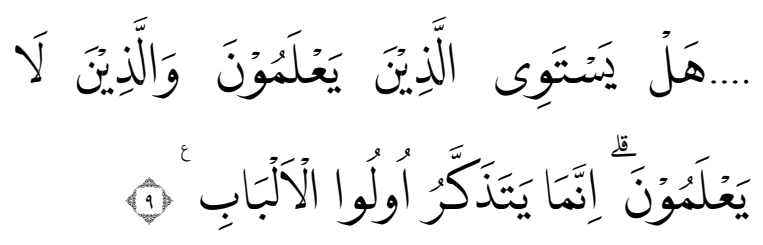

Meaning:

Are those who know equal to those who do not know? Only they will remember (who are) people of understanding. (Q.S. 39: 9)

According to Quraish Shihab, this verse describes someone who knows about a person and his attributes. There is a difference between people who know and people who don't know (Shihab, 2013: 57). People who know, of course, use their minds well. People who know certainly see a lot of things. Then it is a mistake when someone gets information or knowledge from a teacher who he does not know.

This is where the importance of tarikh al-ruwah account has a significant role in finding out who the account owner who posted content. Not only limited to knowing his identity but also knowing what he had said before (previous post). Unlike the material that is posted by an anonymous account whose content is unknown by the owner, then here, we can use al-jarh wa 
ta'dil content to research and clarify the content more precisely.

\section{b. Al-jarh wa Ta'dil Content}

After seeing a post with the date of tarikh al-ruwah account, but not found the real account that posted the first content. Furthermore, it can be researched or analyzed with al-jarh wa ta'dil content consisting of indicators, including:

1) Posts Present Fair Information

Posts may be shared content that does not discredit any party. While content that contains unfair or biased matters such as the Ustadz Abdul Somad case above may not be shared. Basically, the posted content must be fair in judging something and should avoid hoax. As contained in the letter an-Nur verse 11:
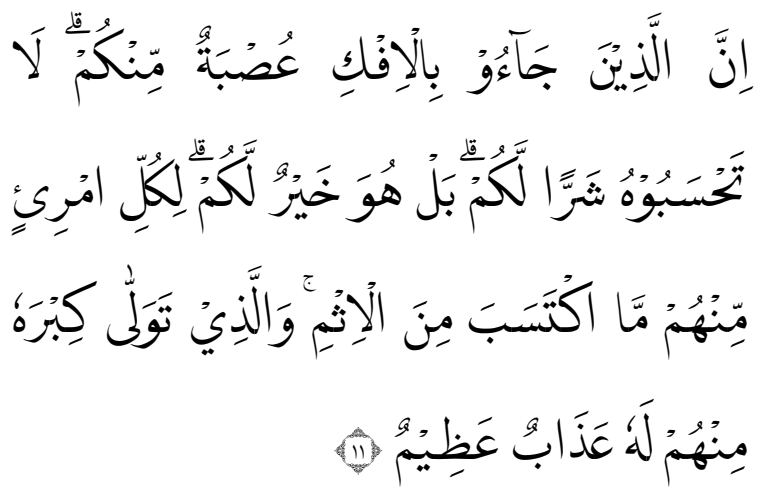

Meaning:

Indeed, those who came with falsehood are a group among you. Do not think it bad for you; rather it is good for you.

For every person among them is what (punishment) he has earned from the sin, and he who took upon himself the greater portion thereof - for him is a great punishment. (Q.S. 24: 11)

Usamah ar-Rifai'i (2008: 352), in his Tafsirul Wajib explains this verse that there is the word al-ifk, which means the worst and most heinous of lies. Then in this verse, there is a word usbah. According to M. Quraish Shihab (2002: 296), in his Tafsir al-Misbah states that the word usbah comes from the asaba vocabulary means hard. Departing from this vocabulary, the term mu'assib means fanatical. Certain groups often interpret this word with an invitation to thought in spreading negative things and damaging one's right name. Whereas in Islam, it has been taught that humans should always speak correctly and not destroy a person's right name, as contained in Surah al-Ahzab verse 70:

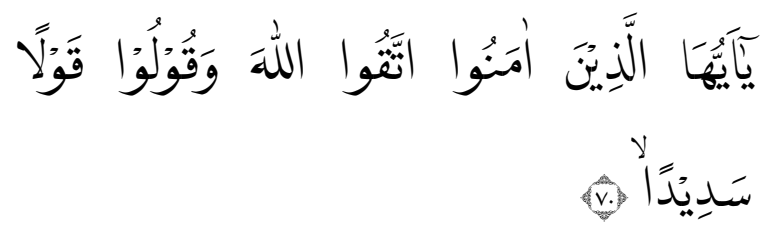

Meaning:

O you who have believed, fear Allah and speak words of appropriate justice.

(Q.S. 33: 70)

2) See the Posting Date

Seeing the posting date means knowing when the events in the news/ content posted are first loaded on the Internet. Sometimes hoax does post news that has been posted before and then repost in the present. For example, a post about the death of a student on a demo that occurred on September 25, 2019, on behalf of Zainal, who was beaten by the authorities. However, after clarification, it turns out that the event had happened a long time ago, namely, on September 30, 2014 (Jawapos.com, 2019). It is important to see when an event occurs as the meaning contained in Surat al-Hasyr verse 18:

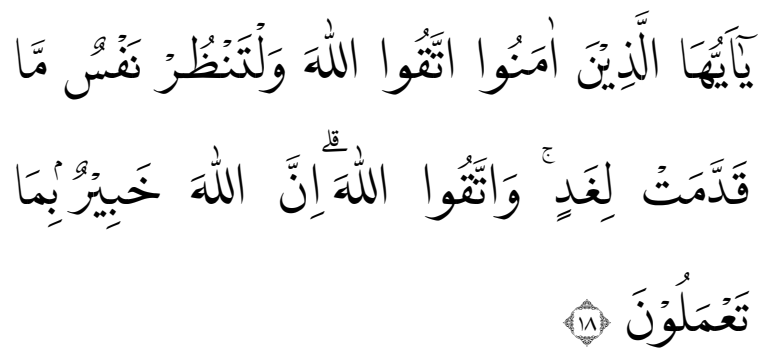

Meaning: 
O you who have believed, fear Allah. And let every soul look to what it has put forth for tomorrow - and fear Allah. Indeed, Allah is Acquainted with what you do. (Q.S. 59: 18)

\section{3) A Bright Source of Information}

Any news or data received is an obligation to know the cause (Bukar \& Ibrahim, 2020: 80). Because the source is the basis that will strengthen when they want to convey the information to others (Witro, 2018: 188). Similarly, sanad is one of the authentic indicators of a hadith. "Ibn Mubarak stated that a sanad is a part of religion, if there is no sanad, then people will say as they wish" (al-Hakim, 1977: 6). In accepting posts containing various information, Internet users must skeptical (Batchelor, 2017) clarify to the source to avoid hoax. As explained in Surah alHujurat verse 6:
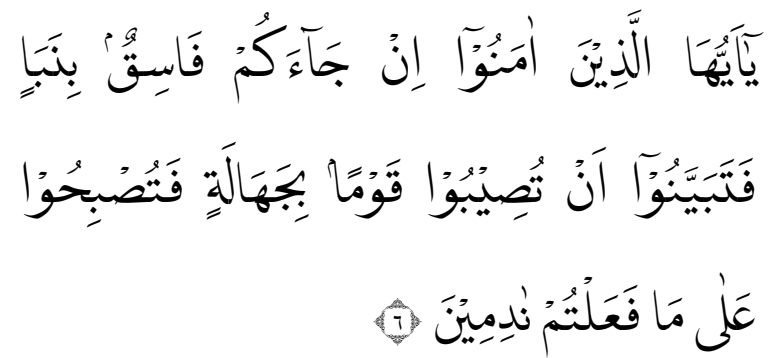

Meaning:

O you who have believed, if there comes to you a disobedient one with information, investigate, lest you harm a people out of ignorance and become, over what you have done, regretful. (Q.S. 49: 6)

According to Aidh al Qarni (2008: 153), this verse is a suggestion to clarify and be careful in receiving news from the wicked. Muslims are asked to be cautious in accepting any story that comes from anyone. This verse also confirms to do the confirmation every report received in any condition. This is nothing but aimed at avoiding false news (hoax). As hoax can cause discord and hostility. Even in this verse, the person who spreads the hoax is significantly denounced by Allah s.w.t.

\section{4) Complete information}

When clarifying posts on social media or websites, one way is to see whether the posts are entire or not. There are a lot of contents that have been posted that are not entirely intact. For example, when the video of the National Police Chief was spread, Tito Karnavian said he could shoot the people who were against him and even killed him. Elements cut actual 15-minute videos to 9 minutes. Whereas in the full version, the National Police Chief addressed the statement to the motorcycle gang that often carried machetes who wanted to kill the people so that the motor gang could be shot (Suara.com, 2019). Similar events have happened to unbelievers who understand the Al-Quran, not as a whole, and thus doubt its truth. As explained by Allah in verse al-Ahqaf verse 11:

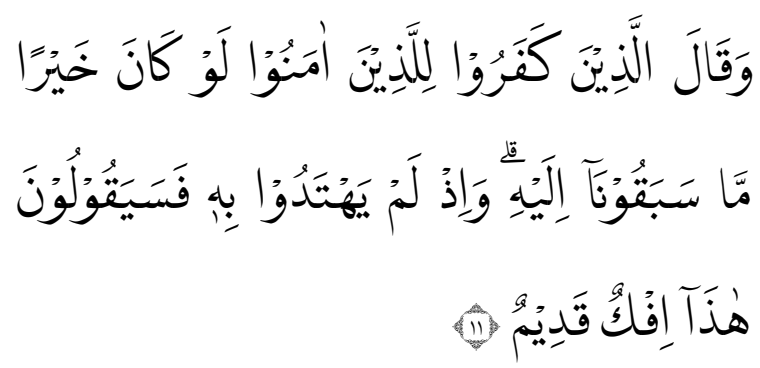

Meaning:

And those who disbelieve say of those who believe, "If it had (truly) been good, they would not have preceded us to it". And when they are not guided by it, they will say, "This is an ancient falsehood". (Q.S. 46: 11)

5) Content Language Must be Polite

In the posting, posts should use respectful language, do not use language that is mocking and criticizing. Even if 
someone makes a mistake, then deny him in a right way, not offending and hurting him. Allah forbids someone to mock and criticize others as contained in al-Hujurat verse 11:
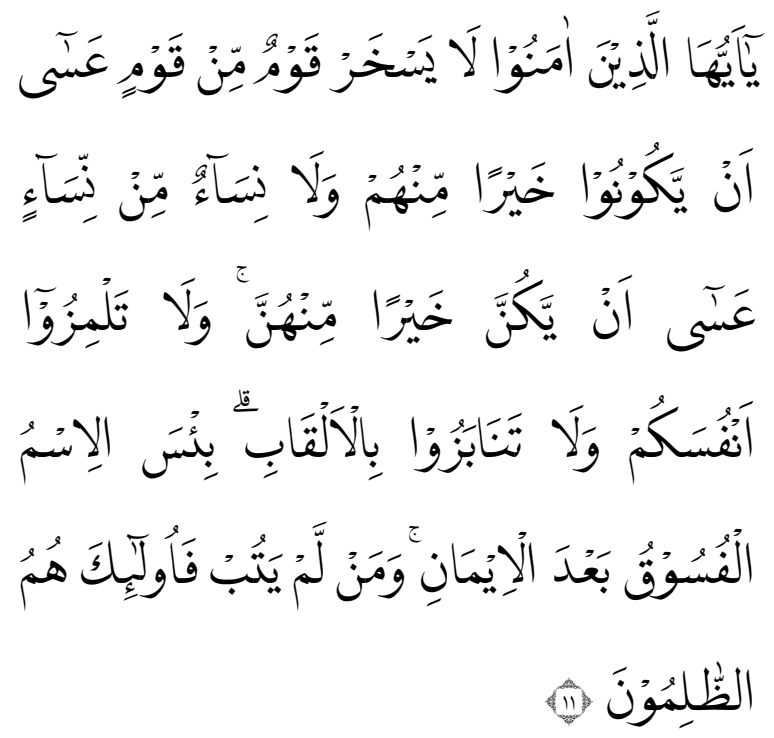

Meaning:

O you who have believed, let not a people ridicule (another) people; perhaps they may be better than them; nor let women ridicule (other) women; perhaps they may be better than them. And do not insult one another and do not call each other by (offensive) nicknames. Wretched is the name of disobedience after (one's) faith. And whoever does not repent - then it is those who are the wrongdoers. (Q.S. 49: 11)

In the above verse, the word yaskhar means to make fun of or to mention the shortcomings of others to humiliate, ridicule, both through words and actions (Shihab, 2002: 606). The mention of qaum and nisa emphasizes women, which in this letter is alluded to as part of qaum and nisa 'in particular. Furthermore, lafaz al-lamzu means to denounce and curse both through speech and behavior. Some interpret it as mockery and threatening either through speech, gestures, or directly.

The above verse is a prohibition against self-defeating and others. The context of the poem is alluded to by the AlQuran in His other words, namely in surah al-Humazah verse 1. Furthermore, lafaz tanaabazuu from the name an-nabz means a wrong title, or an inappropriate call and tends to lead to a call that has negative connotations and pronunciations. This shows the meaning of each other so that both are both dubbed with an unfortunate nickname (Katsir, 1994: 486).

In the current context Internet, users must post content using polite language that does not hurt and offends others. When viewed, this verse historically was revealed relating to the Tamin people who mocked the needy from among the friends who looked miserable. Here it is seen that someone who has wealth will feel he is above the poor, who then causes him to be arrogant with what he has. This attitude is often practiced by people who are fanatics who are very passionate about wealth. Though not necessarily, the mocking is better than being ridiculed.

\section{CONCLUSION}

Rijalul posting is people who are around the post, namely people who make posts, people who receive posts, and people who re-post content on the Internet. Rijalul posting is divided into two; first, tarikh alruwah account is a way to clarify posts by looking at the identity of an account and history (previous posts); and secondly, aljarh wa ta'dil content account is a way to clarify posts with details measured by several indicators, namely the posts present fair information, see the date of posting, the source of information must be bright, the information is complete, and the language 
Doli Witro

of the post must be polite. When a post meets the indicators formulated in the post, then the post can be shared on the website or social media.

\section{REFERENCES}

\section{Books}

Al-Hakim. Ma'rifah 'Ulum al-Hadits. Madinah: al-Maktabah al-Maktabah al-'Imiyah, 1977.

Al-Khatib, Muhammad Ajaj. As-Sunah Qabla at-Tadwin. Kairo: Maktabah Wahbah, 1975.

Al-Khatib, Muhammad Ajaj. Usulul Hadits Ulumuhu Wa Musthalahu. Lebanon: Dar al Fikri, 1989.

Al-Qarni, Aidh. Tafsir Al-Muyassar. Jakarta: Qisthi Press, 2008.

Al-Shaleh, Shubhi. Ulum al-Hadits wa Musthahalahuh. Beirut: Dar al'Ilmi li al-Malayin, 1997.

Ar-Rifai'I, Usamah. Tafsirul Wajib. Depok: Gema Insani, 2008.

Ash-Shiddieqy, Hasbi et. al. Sejarah dan pengantar Ilmu Hadits. Jakarta: Bulang Bintang, 1991.

Departemen Agama RI. Al-Quran dan Terjemahnya. Bandung: Syamil Quran. 2010.

Katsir, Ibnu. Tafsir Ibnu Katsir, (Penerjemah) Abdul Ghoffar dan Abu Ihsana-Atsari. t.kt.: Pustaka Imam Syafi'i, 1994.

Miles, Matthew B. and A. Michael Huberman. Qualitative Data Analysis (a Source book of New Methods). Beverly Hills: Sage Publications, 1984.
Shihab, M. Quraish. Secercah Cahaya Ilahi, Hidup Bersama Al-Quran. Bandung: Mizan.

Shihab, M. Quraish. Tafsir al-Misbah: Pesan, Kesan dan Keserasian AlQuran. Volume 9. Jakarta: Lantera Hati, 2002.

Shihab, M. Quraish. Tafsir al-Misbah: Pesan, Kesan dan Keserasian AlQuran. Volume 12. Jakarta: Lantera Hati, 2002.

Solahudin, and Agus Suyadi. Ulumul Hadits. Bandung: CV Pustaka Setia, 2009.

Tim Penyusun. Hasil Survei Wabah Hoax Nasional 2019. Jakarta: Masyarakarat Telematika (Mastel) Indonesia, 2019.

University, Oxford. Oxford: Learner's Pocket Dictionary. Oxford: Oxford University Press, 2011.

\section{Journals}

Adli, Muhammad \& Sulaiman. "Penanganan Hoaks Berdasarkan Hukum Adat Aceh". Wawasan: Jurnal Ilmiah Agama dan Sosial Budaya, Vol. 3, No. 2, 2018.

Alimi, Moh Yasir. "Theorizing Internet, Religion and Post truth An Article Review". Komunitas: International Journal of Indonesian Society and Culture, Vol. 11, Nol. 2, 2019.

Allcott, Hunt and Gentzkow, Matthew. "Social Media and Fake News in The 2016 Election", Journal of Economic Perspectives, Vol. 31, No. 2, 2017.

Aziz, Mokhamad Abdul, "Netizen Jurnalisme dan Tantangan Dakwah 
Urgency Rijalul Posting...hal. 38-49

Di Media Baru”. Islamic Comunication Journal, Vol. 3, No. 2, 2018.

Balmas, Meital. "When Fake News Becomes Real: Combined Exposure to Multiple News Sources and Political Attitudes of Inefficacy, Alienation, and Cynicism". Communication

Research, Vol. 41, No. 3, 2014.

Batchelor, Oliver. "Getting Out The Truth: The Role of Libraries in The Fight Against Fake News". Reference Services Review, Vol. 45, No. 2, 2017.

Bukar, Modu Alhaji \& Ibrahim, Adamkolo Mohammed. "Hate Speech and Nigeria's Struggle for Democratic Consolidation: A Conceptual Review”. International Journal of Journalism and Mass Communication. Vol. 6, No. 1, 2020.

Imron, Ali. "Dasar-Dasar Ilmu al Jarh Wa Ta'dil”. Mukaddimah: Jurnal Studi Islam, Vol. 2, No. 2, 2017.

Khotimah, Nurul, "Tantangan Independensi Media Dalam Pemilu: Kasus Kompas.com". Islamic Communication Journal, Vol. 4, No. 2, 2019.

Maulana, Luthfi. "Kitab Suci dan Hoax: Pandangan Al-Quran dalam menyikapi Berita Bohong". Wawasan: Jurnal Ilmiah Agama dan Sosial Budaya, Vol. 2, No. 2, 2017.

Mukhtar, Mukhlis. "Penelitian Rijal alHadits sebagai Kegiatan Ijtihad". Jurnal Hukum Diktum, Vol. 9, No. 2, 2011.

Rachman. Margareta Aulia. "Assessing library science programme students' method in countering hoax on social media". Library Philosophy and Practice, 2019.

Santoso, Amanda P. et. al. "Pengaruh Konten Post Instagram terhadap Online Engagement: Studi Kasus pada Lima Merek Pakaian Wanita". Jurnal Teknik ITS, Vol. 6, No. 1, 2017.

Sellnow, Timothy L., Parrish, Adam, and Semenas, Lauren. "From Hoax as Crisis to Crisis as Hoax: Fake News and Information Disorder as Disruptions to the Discourse of Renewal". Journal of International Crisis and Risk Communication Research, Vol. 2, No. 1, 2019.

Sohari. "Urgensi Ilmu Rijal al-Hadits dalam Periwayatan”. Al-Qalam, Vol. 13, No. $68,1997$.

Wirdiyana, Salwa Sofia, "Hoaks dan AlQuran: Upaya Kritis dan Beradab Dalam Menerima Berita Dalam Berkomunikasi”. Islamic Communication Journal, Vol. 4, No. 2, 2019.

Witro, Doli, "Problematika Hoax di Media Sosial: Telaah Pesan Tabayyun dalam Surat al-Hujurat/49: 6", Proceedings of the 3rd BUAF (Borneo Undergraduate Academic Forum), Institut Agama Islam Negeri (IAIN) Palangkaraya, Kalimantan Tengah, Indonesia, 17-19 Oktober 2018.

Witro, Doli. "Peaceful Campaign In Election Al-Hujurat Verse 11 Perspective". Alfuad:Jurnal Ilmu Sosial Keagamaan, Vol. 3, No. 2, 2019.

\section{Internets}


Cek Hoax, [Hoax] Ustadz Abdul Somad Selingkuh (Online), News on http://stophoax.id/blog/post/hoaxustadz-abdul-somad-selingkuh, accessed on 26 October 2019.

Detiknews, Wamena Rusuh Polda: Ucapan Rasis Guru di Wamena Hoax (Online), News on http://news.detik.com/berita/d4718220/, accessed on 26 October 2019.

Jawapos.com, 2019, Aksi Demo Mahasiswa Diboncengi Hoax (Online), News on http://www,jawapos.com/hoax-ataubukan/, accessed on 26 October 2019.

Kamus Besar Bahasa Indonesia Dalam Jaringan (Daring), Look on the site http://kbbi.kemendikbud.go.id/entri/h oax, accessed on 26 October 2019.

Kominfo, Kominfo Blokir 800 Ribu Situs Negatif (Online), News on http://kominfo.go.id/content/detail/10 445/, accessed on 26 October 2019.

Kominfo, Mengenal AIS, Mesin Pengais Konten Negatif Milik Kominfo (Online), News on http://kominfo.go.id/content/detail/12 252/, accessed on 26 October 2019.

Suara.com, Cek Fakta: Hoax, Video Kapolri Tito Bilang Masyarakat Boleh Ditembak (Online), News on http://www.suara.com/news/2019/05/ 23/, accessed on 8 November 2019. 